\title{
CATARACT EXTRACTIONS WITHOUT TRACHEAL INTUBATION
}

\author{
A.E. Delilkan, M.B.B.S., F.F.A.R.C.S., A.M., ${ }^{1}$ and S. ChandRAN, M.B.B.S., F.R.C.S., D.C. ${ }^{2}$
}

\section{INTHODUCTION}

Tracheal intubation as part of the general anaesthetic technique is vital in certain situations.

i. General Anaesthesia for emergency surgical procedures where stomach content is in doubt. A cuffed tracheal tube seals off the respiratory tree and provides protection against the potential danger of aspiration.

ii. When muscle relaxants and controlled ventilation are used. The tracheal tube ensures that the stomach is not distended with gases.

iii. When the patient is positioned on the operating table in such a fashion that it is not possible to maintain patency of the respiratory passage with an oropharyngeal airway and masks, as in the prone position.

iv. In head and neck surgery where holding a mask over the patient's face will interfere with the site of operation.

Tracheal intubation is usually accepted as indicated for general anaesthesia for ophthalmic surgery. It is also accepted that the tracheal tube can be a factor in causing a rise in intraocular pressure. The rise in intraocular pressure caused by coughing or straining during or after tracheal intubation ${ }^{1}$ might thus contribute to ophthalmic complications after cataract extraction (iris prolapse, corneal dehiscence) besides the more potent factor of a poor surgical technique (suturing).

The answer to this paradoxical situation is to use a technique of general anaesthesia which does not require tracheal intubation for maintenance of airway patency while still maintaining adequate respiration and safety of the patient.

A three-year review of the incidence of ophthalmic complications following cataract extractions was carried out by the present authors. ${ }^{2}$ Following this the present study was planned to evaluate the role of tracheal intubation as a factor contributing to ophthalmic complications during and following cataract extractions carried out under general anaesthesia, to determine whether a technique of general anaesthesia without tracheal intubation is safe for the patient while leading to a significantly smaller incidence of ophthalmic complications.

\section{Material ANd Method}

During the period January, 1971 to December, 1972, 135 cases listed for elective cataract extraction under general anaesthesia were studied. Their average age was 58 years (range $41-82$ years) and average weight $44.2 \mathrm{kgm}$ (range 31.5 to $76.4 \mathrm{kgm}$ ).

From the Department of Anaesthesiology ${ }^{1}$ and the Department of Ophthalmology, ${ }^{2}$ University of Malaya, Kuala Lumpur, Malaysia. 
TABLE I

Standardization of Pre-anaesthetic Medication (Intramuscular Meperidine and Promethazine)

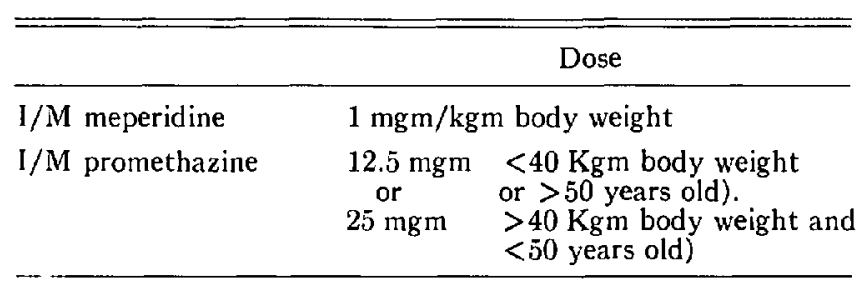

TABLE II

Standardization of Induction Drugs (Intravenous Atropine, Methohexitone aNd GaLlamine Triethiodide in ONE SVRINGE

\begin{tabular}{ll}
\hline & \multicolumn{1}{c}{ Dose } \\
\hline I/V atropine sulphate & $0.4 \mathrm{mgm}$ \\
I/V $1 \%$ methohexitone & $1 \mathrm{mgm} / \mathrm{kgm}$ body weight \\
& $<50$ years old to nearest next higher \\
& $10 \mathrm{mgm}$. \\
& $>50 \mathrm{years}$ old to nearest next lower \\
& $10 \mathrm{mgm})$ \\
& $20 \mathrm{mgm}(<70 \mathrm{Kgm}$ body weight $)$ \\
I/V gallamine triethiode & $40 \mathrm{mgm}(>70 \mathrm{Kgm}$ body weight $)$ \\
\hline
\end{tabular}

Anaesthetic management of all cases was by the same anaesthetist (author A.E.D.) and surgical management by surgeon (co-author S.C.). Pre-anaesthetic assessment was carried out the day before operation and an arterial blood sample was taken for analysis. Pre-anaesthetic medication was standardized with intramuscular meperidine and promethazine (Table I). All were induced with $1 \%$ methohexitone intravenously from a syringe also containing atropine sulphate and gallamine triethiodide (Table II). The larynx was sprayed with 4 per cent topical lignocaine and intubation (when performed) was facilitated by administration of 75 to $100 \mathrm{mgm}$ of suxamethonium chloride. Maintenance of anaesthesia was by nitrous oxide, oxygen and halothane with spontaneous respiration.

The first 80 cases were managed as they presented in the following sequence:

Group 1 (20 cases): Tracheal intubation and spontaneous respiration with a Mapleson "A"3 semi-closed circuit (2.5 litres $\mathrm{O}_{2,3}, 5.5$ litres $\mathrm{N} .2 \mathrm{O}$, Halothane 1.0-1.5 per cent from a Fluotec Mark II vaporizer).

Group 2 (20 cases): Same as Group 1, except that intubation was not performed, and the airway was maintained with a Waters metallic oropharyngeal airway connected to the Oxford pattern airway cap. Gas leaks from the mouth were obliterated by adhesive strapping and a nose-clamp sealed off any leaks from the nostrils. The chin was held up by an 18-inch strip of $\frac{1}{2}$ in. or $\frac{3}{4}$ in. tape split longitudinally for six inches forming a Y-strip. The stem of the Y-plaster strip was struck down over the bridge of the nose, carried over the head and firmly anchored to the edge of the head end of the table. The limbs of the Y-strip were brought together under the chin. Firm anchorage maintained the head in extension (see Figures 1,2 and 3).

Group 3(20 Cases): Tracheal intubation with spontaneous respiration in a closed 


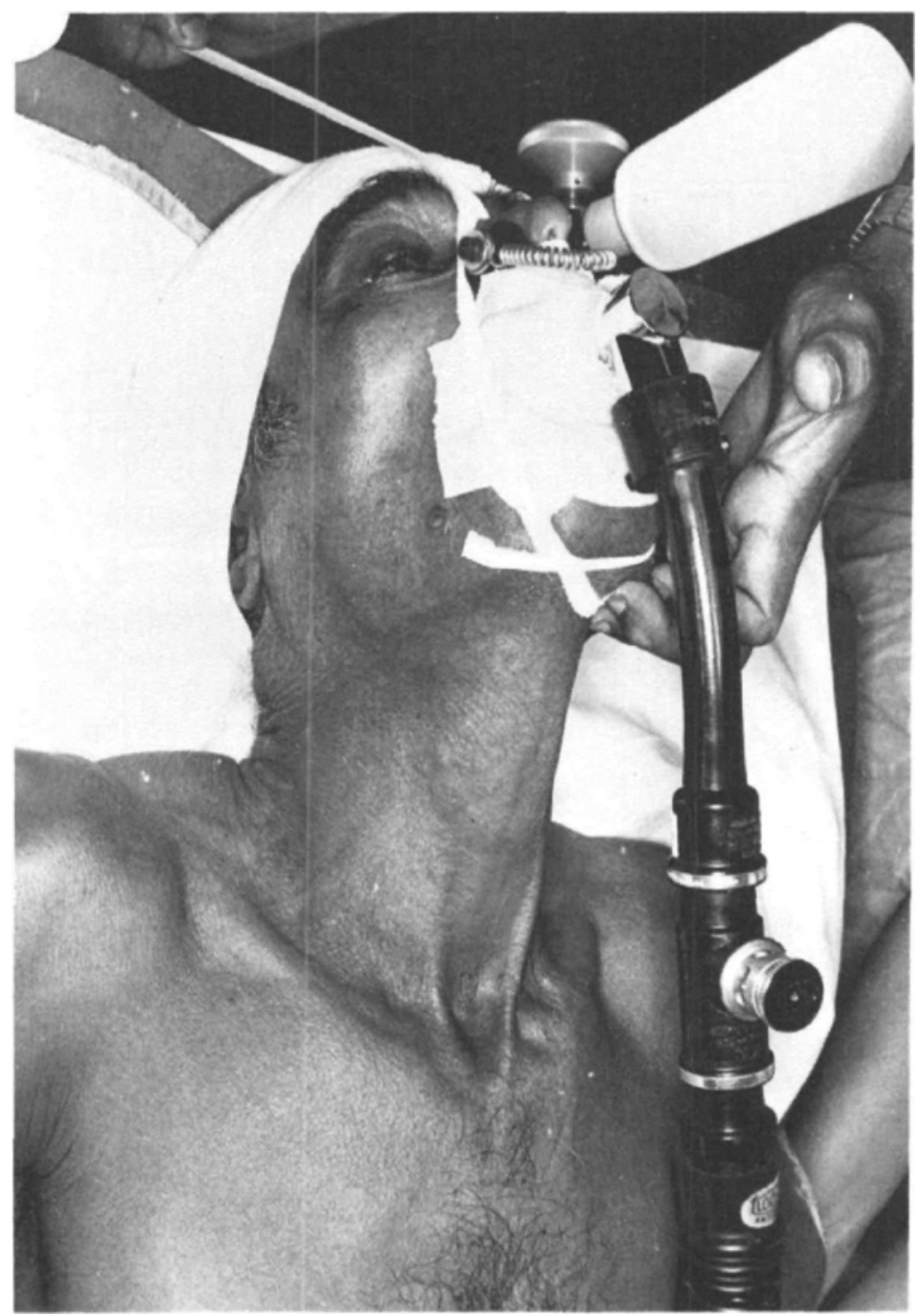

FIGURE 1. Showing the arrangement without intubation using adhesive tape and a nose clamp to seal off leaks. The Y-tape strip maintains extensions of the hend.

circle circuit ( $300 \mathrm{ml}$ oxygen flow) and halothane from a Goldman vaporizer in circuit (V.I.C.).

Group 4(20 Cases): Same as Group 3, except that intubation was not performed. Airway maintenance was as in Group 2.

After the first 80 cases the remaining 55 patients were managed in an alternating sequence as in Groups 1 and 2 without arterial blood gas analysis. A clinical impression was gained from the initial 80 cases that the Mapleson " $A$ " semi-closed circuit provided more safety for the patients who were not intubated. The Group 3 and Group 4 sequences were thus stopped.

All intubated patients were extubated while on maintenance levels of anaesthesia to prevent coughing or straining. 


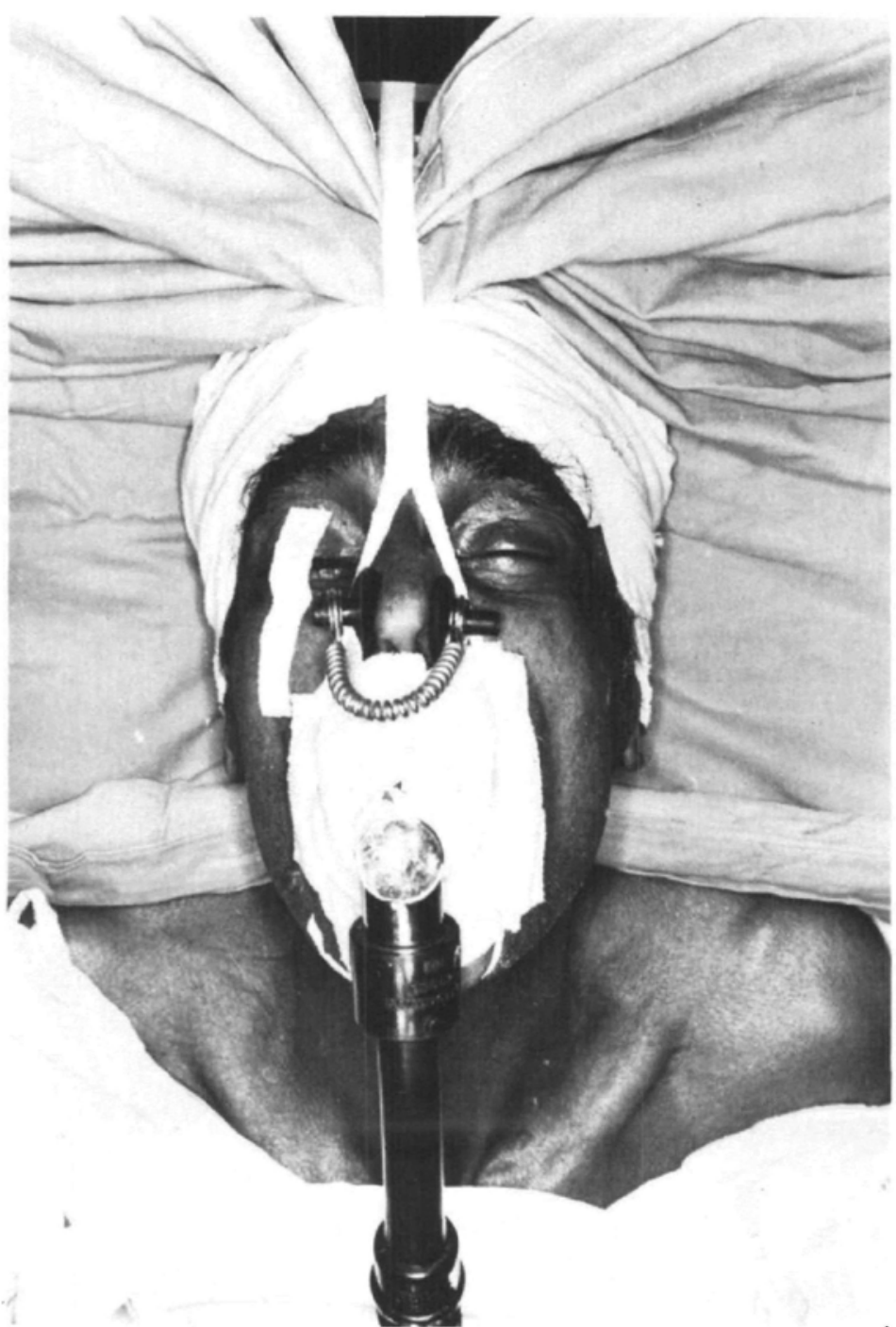

Ficure 2. Showing a front view of the same non-intubated patient ready for draping.

During operation an arterial blood sample was taken after 10 minutes of established maintenance anaesthesia. Palpation of the radial artery and blood pressure recordings (by palpation) was done at two-minute intervals and any pulse irregularity or bradycardia (rate $<60 /$ minute) was noted. The anaesthetist listened to the heart-beat and left-lung air-entry continuously with a precordial stethoscope. During the operation the surgeon noted any bulging of the iris and/or vitreous loss, any haemorrhage from the corneo-scleral or iris incision and these constituted the peroperative complications.

All the arterial blood samples (pre- and per-operative) were analyzed using the Clarke Type $\mathrm{E} 5046 \mathrm{PO}_{2}$ electrode; $\mathrm{pH}, \mathrm{PCO}_{2}$ and base excess/deficit were measured by the technique described by Astrup ${ }^{4}$ using the Siggard-Andersen nomogram. ${ }^{5}$ In the recovery room and on the ward any coughing, sore-throat, 
DELILKAN \& CHANDRAN: CATARACT EXTRACTIONS WITHOUT TRACHEAL INTUBATION 411

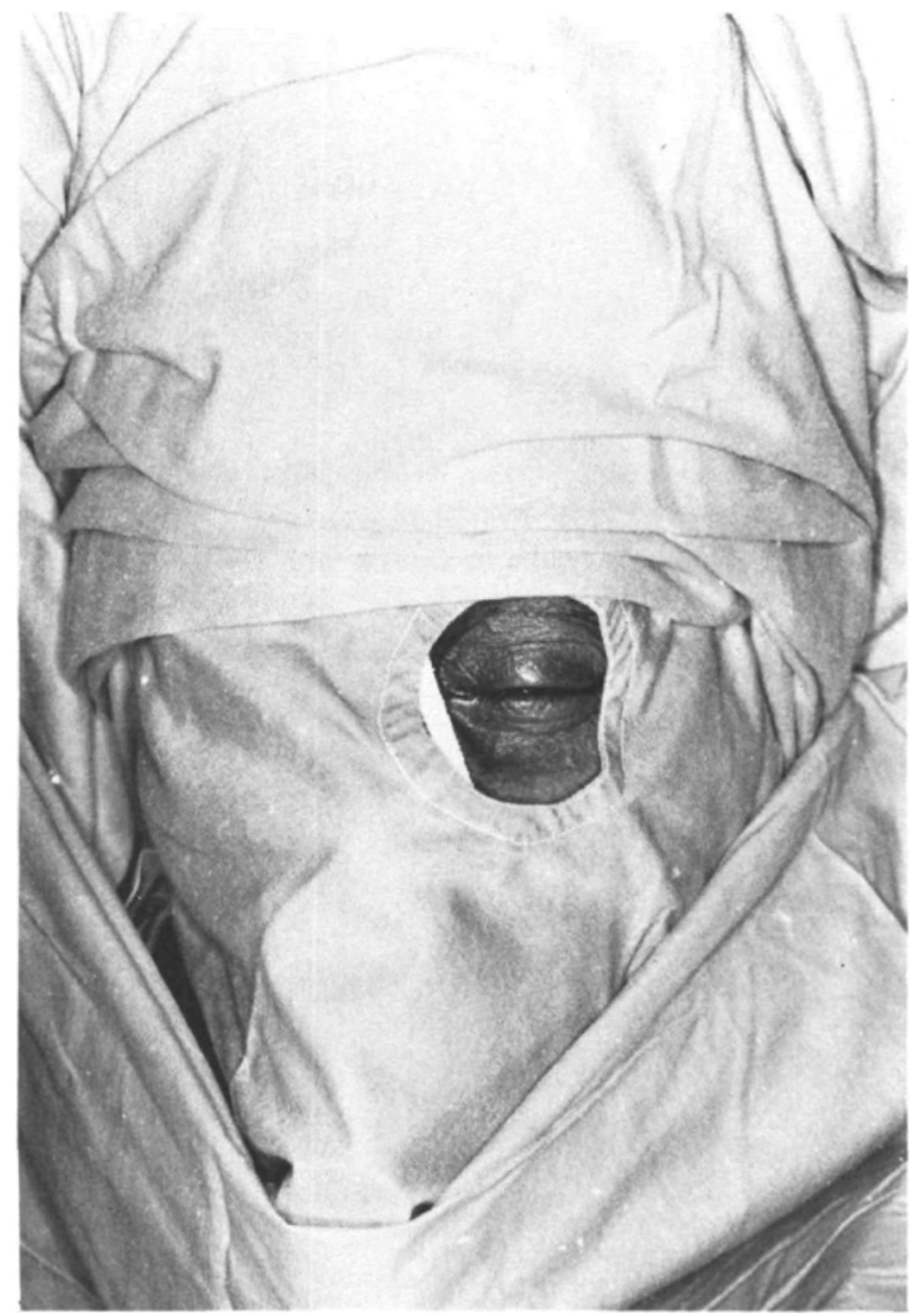

Figune 3. Showing the non-intubated patient draped and ready for left catarict extraction.

nausea and/or vomiting within the first 24 hours was noted. Any patient requiring re-operation within 14 days because of prolapsed iris, corneal dehiscence or flat anterior chamber was considered to have a post-operative ophthalmic complication.

\section{RESUlts}

The average operative time for the 135 cases was 24.5 minutes and the average anaesthetic time was 30.2 minutes.

Table III shows that the incidence of postoperative ophthalmic complications in the 68 intubated cases ( 11.76 per cent) was statistically significantly higher $(\mathrm{P}=0.05)$ than in the 67 patients who were not intubated $(2.99$ per cent $)$.

The incidence of complications during operation was also higher $(P<0.05)$ in 
TABLE III

\begin{tabular}{|c|c|c|c|c|}
\hline & \multirow[b]{2}{*}{$\begin{array}{l}\text { Intubated } \\
\text { Cases }(68)\end{array}$} & \multirow[b]{2}{*}{$\begin{array}{l}\text { Not intubated } \\
\text { Cases }(67)\end{array}$} & \multicolumn{2}{|c|}{ Statistical significance } \\
\hline & & & $\begin{array}{c}X^{2} \\
(n=1)\end{array}$ & $P$ \\
\hline $\begin{array}{l}\text { No. of Cases With } \\
\text { Peroperative } \\
\text { Complications }\end{array}$ & $13(19.12 \%)$ & $5(7.46 \%)$ & 4.1 & $<0.05$ \\
\hline $\begin{array}{l}\text { No. of Cases With } \\
\text { Post-operative } \\
\text { Complications }\end{array}$ & $8(11.76 \%)$ & $2(2.99 \%)$ & 3.88 & $=0.05$ \\
\hline
\end{tabular}

Showing the incidence of ophthalmic complications during and after operation in the intubated cases compared to those not intubated and the statistical significance of the differences.

"Per-operative ophthalmic complication": iris-bulge and/or vitreous loss, haemorrhage.

"Post-operative ophthalmic complications": iris prolapse, corneal dehiscence or flat anterior chamber.

TABLE IV

\begin{tabular}{|c|c|c|c|c|c|}
\hline & \multirow[b]{2}{*}{$\begin{array}{l}\text { Incidence in } \\
\text { all Cases (135) }\end{array}$} & \multirow{2}{*}{$\begin{array}{c}\text { Incidence in } \\
\text { Intubated Cases } \\
(68)\end{array}$} & \multirow{2}{*}{$\begin{array}{l}\text { Incidence in } \\
\text { not Intubated } \\
\text { Cases (67) }\end{array}$} & \multicolumn{2}{|c|}{$\begin{array}{l}\text { Statistical } \\
\text { Significance }\end{array}$} \\
\hline & & & & $\left(n \stackrel{X^{2}}{=} 1\right)$ & $\mathrm{P}$ \\
\hline $\begin{array}{l}\text { Coughing within } \\
\text { first } 24 \text { hours } \\
\text { postoperatively }\end{array}$ & $61(45.19 \%)$ & $47(69.12 \%)$ & $14(20.9 \%)$ & 30.6 & $\ll 0.01$ \\
\hline $\begin{array}{l}\text { Sore-throats } \\
\text { within first } \\
24 \text { hours } \\
\text { postoperatively }\end{array}$ & $56(41.45 \%)$ & $44(64.7 \%)$ & $12(17.91 \%)$ & 31.2 & $\ll 0.01$ \\
\hline $\begin{array}{l}\text { Nausea and/or } \\
\text { vomiting within } \\
\text { first } 24 \text { hours } \\
\text { postoperatively }\end{array}$ & $12(8.89 \%)$ & $7(10.24 \%)$ & $5(7.46 \%)$ & 0.38 & $>0.8$ \\
\hline
\end{tabular}

The incidence of postoperative (first 24 hours) coughing, sore-throat nausea and/or vomiting in intubated and not intubated cases and the statistical significance of the differences.

the intubated cases ( 19.12 per cent) than in those not intubated ( 7.46 per cent). Eight of the 13 intubated cases (61.54 per cent) with complications during operation also developed postoperative ophthalmic complications compared to two of the five patients who were not intubated (Table III).

The incidence of coughing and sore throat (69.12 per cent and 64.7 per cent) were also higher $(\mathrm{P}<<0.01)$ in the intubated cases than in those not intubated ( 20.9 per cent and 17.91 per cent) as shown in Table IV. The difference in the incidence of nausea and/or vomiting was statistically not significant $(P>0.8)$.

The mean rise in $\mathrm{PaCO}_{2}$ between the pre-anaesthesia and intra-operative values of the four groups was analyzed. Comparing this mean value in Groups 1 and 3 (see Table V) it was evident that the mean rise was significantly greater in Group 3 $(\mathrm{P}<<0.01)$. Comparing Groups 2 and 4 it was found that the mean rise was again significantly greater in Group $4(\mathrm{P}<<0.01)$. These results from Table $\mathrm{V}$ show statistically in a significant manner $(\mathrm{P}<<0.01)$ that from the point of respiration 
TABLE 5

\begin{tabular}{|c|c|c|c|}
\hline & \multirow{2}{*}{$\begin{array}{l}\text { Mean of rise in } \\
\mathrm{PaCO}_{2}(\mathrm{mmHg}) \text { with } \\
\text { Standard Deviation }\end{array}$} & \multicolumn{2}{|c|}{ Statistical significance } \\
\hline & & $" \mathrm{t} "$ & $P$ \\
\hline $\begin{array}{l}\text { Group } 1 \\
\text { (20 cases) } \\
\text { Group } 3 \\
\text { (20 Cases) }\end{array}$ & $\begin{array}{l}10.2( \pm 6.1) \\
23.7( \pm 6.2)\end{array}$ & 6.96 & $\ll 0.01$ \\
\hline $\begin{array}{l}\text { Group } 2 \\
\text { (20 cases) } \\
\text { Group } 4 \\
\text { (20 Cases) }\end{array}$ & $\begin{array}{l}12.8( \pm 6.2) \\
29.8( \pm 5.0)\end{array}$ & 9.55 & $\ll 0.01$ \\
\hline $\begin{array}{l}\text { Comparir } \\
\text { pre- and pe } \\
\text { Statistical } \\
\text { "Group I } \\
\text { son "A" cir } \\
\text { "Group 3 } \\
\text { circle circui } \\
\text { "Group 2 } \\
\text { "Group 4 }\end{array}$ & $\begin{array}{l}\text { lifferences in the mean } \\
\text { ive values) in Groups } \\
\text { nce shown. } \\
\text { hea intubated; spontant } \\
\mathrm{O} / \mathrm{O}_{2} \text { /Halothane). } \\
\text { hea intubated; spontan } \\
\text { oda lime absorption an } \\
\text { e as "Group 1" except } \\
\text { e as "Group 3" except }\end{array}$ & $\begin{array}{l}\text { rise in } \\
\text { and ir } \\
\text { piratio } \\
\text { piratio } \\
\text { uriser-i } \\
\text { bation } \\
\text { bation }\end{array}$ & $\begin{array}{l}\text { between } \\
2 \text { and } 4 . \\
\text {; Maple- } \\
\text {; closed, } \\
\text { V.I.C.). } \\
\text { d. } \\
\text { d. }\end{array}$ \\
\hline
\end{tabular}

the semi-closed Mapleson "A" circuit is safer than the closed circle circuit (VIC/halothane) especially when the trachea is not intubated. Six patients in Group 3 (30 per cent) and twelve (60 per cent) in Group 4 (Groups 3 and 4 closed circle VIC/Halothane) showed pulse irregularities or bradycardia. This was not seen in patients of Groups 1 and 2 (Mapleson " $A$ " circuit).

\section{Discussion}

From the point of view of anaesthesia, the basic requirements for intraocular surgery are control of intraocular pressure (no sustained rise should occur) and control of restlessness during and after the operation. Anaesthesia for cataract extraction can be managed with local analgesia, local analgesia with heavy sedation (including neurolept-analgesia) or general anaesthesia. Regional analgesia procedures have been thoroughly studied for this purpose, ${ }^{6,7,8}$ Besides their usual limitations (children, apprehensive and unco-operative adults and reactions to local analgesic drugs) they pose a problem particular to a multiracial community where there is inability to communicate because of language difficulties. For a regional procedure to succeed full patient-doctor rapport is necessary. Thus many ophthalmic surgeons ask for general anaesthesia as a first choice for cataract extractions. Regional analgesia is used only if the patient is assessed to be unfit for general anaesthesia.

The factors which can give rise to ophthalmic complications following cataract extraction under general anaesthesia can be either surgical or anaesthetic. Surgical factors include poor suturing of the corneal wound and possibly the use of alphachymotrypsin." The anaesthetic factors include pre-anaesthetic medication (morphine group), tracheal intubation and its consequences, ${ }^{1}$ controlled or spontaneous respiration techniques, ${ }^{2}$ drugs like suxamethonium ${ }^{10}$ and a rise in $\mathrm{PaCO}_{2}$, leading to increased blood flow resulting in raised intraocular pressure. 
In this study we have tried to eliminate the possible variables which can contribute to postoperative complications by standardizing them: one surgeon, one anaesthetist, one pre-anaesthetic medication, identical drugs for induction and for maintenance of anaesthesia with spontaneous respiration. The only difference was tracheal intubation (68 cases) or no intubation (67 cases) in an alternate sequence. The ophthalmic complication rates might thus be attributed to the presence or absence of the tracheal tube.

Administration of halothane to the spontaneously breathing unintubated patient is not a new technique, ${ }^{11}$ but the support of the chin has always been a problem. Satisfactory respiration had to be ensured by manually supporting the patients lower jaw with the anaesthetist's finger beneath the surgical drapes. This is inconvenient and tedious. By using a simple Y-shaped strip of adhesive plaster strapping, the technical problem has been overcome while still maintaining respiratory safety. The only problem so far encountered has been the bearded patient. Four such patients could not be managed without intubation because application of adhesive tape around the mouth was impossible. From the surgeon's point of view the hyperextension of the head made the incision difficult using the ab externo method with conjunctival flap. The solution is to raise the head end of the table so that the plane of the eyeball is brought into the correct position. The result in postural hypotension helps in controlling the intraocular pressure.

\section{Conclusion}

The results show in a statistically significant way that tracheal intubation for cataract extraction gives rise to a higher incidence of ophthalmic complications. Mapleson "A" circuit $\left(\mathrm{O}_{2} / \mathrm{N} . / \mathrm{O} /\right.$ Halothane) is safer than the closed circle circuit $\left(\mathrm{O}_{2} / \mathrm{VIC}\right.$ Halothane), with spontaneous respiration, especially with a technique without tracheal intubation.

The technique without intubation requires meticulous care in setting up and close vigilence during anaesthesia. A skin test should be used to rule out allergy to adhesive tape. Perhaps a justified criticism would be that this is a potentially dangerous technique, which should be used only by the experienced. Facilities for intubation should always be at hand. Ophthalmic surgeons are sometimes paired with the less experienced anaesthetists. ${ }^{12}$ They will welcome a change which requires more experienced anaesthetists and results in better operative conditions.

\section{SUMMARY}

Following a retrospective study of opthalmic complications after cataract extractions a planned study of 135 cases was conducted to compare the complication rates when general anaesthesia was administered with and without tracheal intubation. General anaesthesia without intubation was conducted through an oropharyngeal airway with an airway adaptor for the circuit tubes. A chin support was provided by use of an 18-inch-long strip of adhesive plaster, split for 6 inches to form a Y; the stem of the Y-plaster was anchored to the head of the table and the 
limbs under the chin. Two anaesthetic circuits were studied including arterial blood gas analyses.

The results showed in a statistically significant degree that anaesthesia without intubation was associated with a lower incidence of ophthalmic complications. The patency of the respiratory passages without tracheal intubation provides safe respiration with the Mapleson " $A$ " semi-closed circuit using a simple Y-shaped strip of adhesive tape to hold up the lower jaw and maintain head extension.

\section{RÉSUMÉ}

Les auteurs ont déjà publiée les résultats d'une analyse rétrospective portant sur les complications ophtalmiques reliés à l'emploi d'anesthésie générale dans les cas d'extractions de cataractes. Ils rapportent maintenant les résultats d'une étude prospective au cours du même genre d'intervention. L'objectif a été cette fois-ci de comparer l'incidence de complications ophtalmiques lorsque l'anesthésie générale était administrée avec intubation trachéale ou sans intubation.

Les malades non intubés se ventilaient via une canule métallique oropharyngée reliée au circuit d'anesthésie. La tête était maintenue en extension et le menton était soulevé au moyen d'un long diachylon coupé longitudinalement aux extrémités, puis fixé sur la crête nasale, les extrémités étant fixées d'une part aux côtés de l'extrémité supérieure de la table d'opération et d'autre part sous le menton.

Les auteurs ont trouvé une incidence de complications ophtalmiques abaissées de façon significative chez leurs patients non intubés.

Le circuit semi-fermé “ $A$ ” de Mapleson ${ }^{3}$ s'est avéré supérieur au circuit fermé chez leurs patients. Le maintien de voies respiratoires libres n'a pas posé de problèmes cez les malades grâce au système décrit.

\section{ACKNOWLEDGMENT}

The authors gratefully acknowledge Messrs. Zainal Abidin and G. Navaneetham of the Department of Medical Illustration for the photography and Miss S. Dawood for her secretarial help. Mr. Lai Yeow Hin, Chief of the Medical Records Unit, University Hospital, Kuala Lumpur, is gratefully acknowledged for his help in the statistical analysis.

\section{REFERENCES}

1. Conway, C.M., Miller, J.S., \& Sugden, F.L. Sore throat after anaesthesia. Brit. J. Anaesth. 32: 219-223 (1960).

2. Delilkan, A.E. \& Chandran, S. A three-year review of anaesthesia for cataract extraction. Anaesth. and Analg. 51: 506-508 (1972).

3. Mapleson, W.W. The elimination of rebreathing in various semi-closed anaesthetic systems. Brit. J. Anaesth. 26: 323-332 (1954).

4. Astrup, P., Jorgensen, K., Siggard-Andersen, O., \& Engel, K. The acid-base metabolism: a new approach. Lancet 1 : 1035-1039 (1980).

5. Siggard-Andersen, O. The $\mathrm{pH}-\log \mathrm{PCO}_{2}$ blood acid-base nomogram revised. Scand. J. Clin. Lab. Invest. 14: No. 6 (1961).

6. Ingham, H.V. \& Davison, M.H.V. Intraocular surgery with local analgesic and heavy sedation. Lancet I: 1321-1324 (1961). 
7. Nilsson, E. \& JANSSEN, P. Neuroleptanalgesia - an alternative to general anaesthesia. Acta Anaesth. Scand. 5: 73-84 (1961).

8. Pontinen, P.J., \& Miettinen, P. Neuroleptanalgesia in cataract surgery. Acta Ophthal. Kbh. Suppl. 80, Part 1 (1964).

9. Carbajal, U.M. Complications in cataract surgery from the use of alpha-chymotrypsin. Amer. J. Ophthal. 59: 237-241 (1965).

10. AdAms, A.K. \& BanNeTt, K.C. Anaesthesia and intraocular pressure. Anaesthesia 21 : 202-210 ( 1966).

11. Verner, I.R. General anaesthesia for ophthalmic surgery? Proc. R. Soc. Med. 60: 12801282 (1967).

12. Stallard, H.B. Anaesthesia for ophthalmic surgery. Proc. R. Soc. Med. 60: 1273-1275 (1967). 